\title{
FAKTOR YANG MEMPENGARUHI PENGUNGKAPAN CORPORATE SOCIAL RESPONSIBILITY PADA PERUSAHAAN MANUFAKTUR
}

\author{
Nadya Stevie Khanaya Siahaan \\ Program Studi Akuntansi \\ Fakultas Ekonomi Universitas Katolik Parahyangan \\ Email: \\ Samuel Wirawan \\ Program Studi Akuntansi \\ Fakultas Ekonomi Universitas Katolik Parahyangan \\ Email: samuelwirawan@unpar.ac.id
}

\begin{abstract}
ABSTRAK
Pengungkapan CSR di suatu perusahaan adalah hal yang penting untuk dilakukan oleh perusahaan. Pemerintah sendiri pun sudah membuat peraturan yang mewajibkan bagi perusahaan untuk melakukan pengungkapan CSR. Namun pada kenyataannya, masih banyak perusahaan yang belum melakukan pengungkapan CSR dengan tidak membuat Laporan Keberlanjutan. Ada banyak faktor yang dapat mempengaruhi pengungkapan CSR di suatu perusahaan. Penelitian ini bertujuan untuk mengetahui apakah faktor-faktor tersebut benar memengaruhi pengungkapan CSR. Faktor yang diteliti adalah ukuran perusahaan, kinerja keuangan, dan kinerja lingkungan. Ukuran perusahaan diukur dengan logaritma natural dari total aset perusahaan, kinerja keuangan diukur dengan rasio Return on Assets, kinerja lingkungan diukur dengan peringkat PROPER, dan pengungkapan CSR diukur dengan jumlah komponen yang diungkapkan berdasarkan standar GRI. Penelitian ini adalah penelitian kuantitatif dengan bentuk kausal. Penelitian ini dilakukan terhadap perusahaan manufaktur di Indonesia yang telah menerbitkan laporan keuangan dan laporan keberlanjutan pada tahun 2017 hingga tahun 2019 yaitu sebanyak 10 perusahaan. Data yang telah dikumpulkan dalam penelitian ini kemudian diuji menggunakan software IBM SPSS Statistics 26 dengan beberapa bentuk pengujian, yaitu uji statistik deskriptif, uji asumsi klasik yang terdiri dari uji normalitas, uji multikolinearitas, uji heteroskedastisitas, dan uji autokorelasi, uji statistik t, dan uji statistik F. Hasil dari penelitian ini adalah ukuran perusahaan tidak berpengaruh secara parsial terhadap pengungkapan CSR, kinerja keuangan tidak berpengaruh secara parsial terhadap pengungkapan CSR, kinerja lingkungan tidak berpengaruh secara parsial terhadap pengungkapan CSR, dan ukuran perusahaan, kinerja keuangan, dan kinerja lingkungan tidak berpengaruh secara simultan terhadap pengungkapan CSR.
\end{abstract}

Kata Kunci: Ukuran Perusahaan, Kinerja Keuangan, Return on Assets (ROA), Kinerja Lingkungan, PROPER, Pengungkapan CSR, Standar GRI.

JEL: M41

\section{ABSTRACT}

Disclosure of CSR in a company is an important thing for companies to do. The government itself has also made regulations that require companies to disclose CSR. But in reality, there are still many companies that have not made CSR disclosures by not making a Sustainability Report. There are many factors that can affect CSR disclosure in a company. This study aims to determine whether these factors really affect CSR disclosure. The factors studied were company size, financial performance, and environmental performance. Company size is measured by the natural logarithm of the company's total assets, financial performance is measured by the Return on Assets ratio, environmental performance is measured by the PROPER rating, and CSR disclosure is measured by the number of components disclosed based on GRI standards. This research is a quantitative research with a causal form. This research was conducted on manufacturing companies in Indonesia that have published financial reports and sustainability reports from 2017 to 2019, namely 10 companies. The 
data that has been collected in this study was then tested using IBM SPSS Statistics 26 software with several forms of testing, namely descriptive statistical tests, classical assumption tests consisting of normality test, multicollinearity test, heteroscedasticity test, and autocorrelation test, $t$ statistic test, and test. F statistics. The results of this study are company size does not partially affect CSR disclosure, financial performance does not partially affect CSR disclosure, environmental performance does not partially affect CSR disclosure, and company size, financial performance, and environmental performance do not simultaneously affect CSR disclosure.

Keywords: Company Size, Financial Performance, Return on Assets (ROA), Environmental Performance, PROPER, CSR Disclosure, GRI Standard

\section{PENDAHULUAN}

\section{Latar Belakang}

Program CSR (Corporate Social Responsibility) adalah salah satu program yang wajib dilakukan oleh perusahaan dan telah diatur oleh pemerintah dalam Pasal 74 Undang-Undang no. 40 tahun 2007 mengenai Perseroan Terbatas, tepatnya pada Bab V mengenai Tanggung Jawab Sosial dan Lingkungan. Undang-Undang tersebut menyebutkan dengan jelas bahwa perseroan yang melakukan usahanya di bidang dan/atau berkaitan dengan sumber daya alam wajib melaksanakan tanggung jawab sosial dan lingkungan dan apabila tidak melaksanakan kewajibannya, akan dikenai sanksi sesuai dengan ketentuan peraturan perundang-undangan. Selain itu juga, terdapat Peraturan Otoritas Jasa Keuangan nomor 51/POJK.03/2017 tentang Penerapan Keuangan Berkelanjutan bagi Lembaga Jasa Keuangan, Emiten, dan Perusahaan Publik. Dengan adanya peraturan-peraturan ini, maka dapat disimpulkan bahwa kini kewajiban perusahaan bukan hanya melaporkan kinerja keuangan, tetapi juga menyiapkan laporan yang berhubungan dengan kegiatan yang dilakukan perusahaan untuk mendukung keberlanjutan, yaitu Laporan Keberlanjutan.

Walaupun sudah diwajibkan dalam peraturan perundang-undangan, pada kenyataannya masih banyak perusahaan yang belum melakukan kewajiban ini. Dilansir dari liputan6.com, per 23 April 2019, dari 629 perusahaan yang tercatat di BEI, hanya ada 110 laporan keberlanjutan yang diterbitkan. Tidak hanya perusahaan yang tercatat di BEI yang menjadi perhatian, namun juga Usaha Kecil dan Menengah (Kencana, 2019). Belum ada satupun Usaha Kecil dan Menengah yang menerbitkan Laporan Keberlanjutan. Hal ini menunjukkan bahwa masih kurangnya kesadaran perusahaan untuk membuat Laporan Keberlanjutan di samping membuat Laporan Tahunan atau Laporan Keuangan.

Laporan Keberlanjutan sendiri adalah laporan yang berisi tanggung jawab perusahaan dalam berbagai aspek. Tiga aspek utama yang dilaporkan dalam Laporan Keberlanjutan adalah aspek lingkungan, aspek ekonomi, dan aspek sosial. Laporan Keberlanjutan sendiri memiliki berbagai manfaat antara lain menjaga dan meningkatkan reputasi perusahaan (Setiawati \& Lim, 2018). Dengan membuat Laporan Keberlanjutan, perusahaan memperlihatkan kinerja mereka selain kinerja keuangan. Para stakeholder dapat dengan jelas melihat kegiatan apa saja yang dilakukan perusahaan selama satu periode (Jumingan, 2006). Hal ini menunjukkan bahwa usaha yang dikelola oleh perusahaan tidak hanya berfokus pada profit, melainkan juga memperhatikan dan bertanggung jawab kepada masyarakat sebagai salah satu dari stakeholder. Selain itu, laporan keberlanjutan juga dapat menunjukkan kepada perusahaan mengenai kinerja mereka pada periode tersebut sehingga perusahaan dapat mengevaluasi apakah kinerja sudah baik ataukah ada yang perlu ditingkatkan. Laporan Keberlanjutan memiliki banyak manfaat untuk perusahaan. Namun, banyaknya manfaat dari Laporan Keberlanjutan ternyata belum cukup menjadi alasan 
bagi banyak perusahaan untuk membuat laporan keberlanjutan (Suratno, Darsono, \& Mutmainah, 2007).

Industri manufaktur di Indonesia berkembang pesat. Dilansir dari knic.co.id, per 12 Juli 2019, sektor manufaktur menyumbang peningkatan perekonomian sebesar $20.72 \%$ dan menggeser peran Commodity Based menjadi Manufacture Based. Dengan demikian, Indonesia menjadi basis manufaktur terbesar di Asia Tenggara. Angka Manufacturing Value Added (MVA) untuk industri ini juga menduduki posisi paling atas di antara negara-negara ASEAN dengan mencapai nilai sebesar 4,5 \%. Dalam lingkup global, manufaktur Indonesia berada di peringkat 9 dari seluruh negara yang ada di dunia. (Karawang News Industry City, 2019). Selain itu juga, dilansir dari kemenperin.go.id, selama 2020, walaupun di tengah COVID-19, industri manufaktur terus melaju. Dari data yang telah disebutkan, dapat disimpulkan bahwa perusahaan yang bergerak di bidang manufaktur telah berkembang menjadi salah satu industri yang menyokong perekonomian Indonesia. Dengan demikian, perusahaan manufaktur tentunya banyak menggunakan sumber daya baik alam maupun manusia untuk menjalankan usahanya dan memiliki tanggung jawab terhadap banyak stakeholder. Berdasarkan latar belakang tersebut, maka tujuan dari penelitian ini adalah: mengetahui apakah ukuran perusahaan mempengaruhi CSR; mengetahui apakah kinerja keuangan mempengaruhi pengungkapan CSR; mengetahui apakah kinerja lingkungan mempengaruhi pengungkapan CSR; dan mengetahui apakah ukuran perusahaan, kinerja keuangan, dan kinerja lingkungan secara simultan berpengaruh terhadap pengungkapan CSR.

\section{Ukuran Perusahaan}

Menurut Ferri dan Jones (1979), ukuran perusahaan adalah variabel yang menggambarkan besar kecilnya perusahaan yang ditunjukkan dengan besar kecilnya aktiva, jumlah penjualan, rata-rata tingkat penjualan, dan rata-rata total aktiva (Setiawati \& Lim, 2018). Dari beberapa indikator, yang paling banyak digunakan untuk mengukur ukuran perusahaan ialah total aktiva baik aktiva lancar maupun aktiva tidak lancar (Mandaika \& Salim, 2015).

\section{Kinerja Keuangan}

Kinerja keuangan adalah gambaran kondisi keuangan perusahaan pada suatu periode tertentu baik menyangkut aspek penghimpunan dana maupun penyaluran dana, yang biasanya diukur dengan indikator kecukupan modal, likuiditas, dan profitabilitas (Jumingan, 2006). Kinerja keuangan perusahaan merupakan prestasi yang dicapai perusahaan dalam suatu periode tertentu yang mencerminkan tingkat kesehatan perusahaan tersebut (Sutrisno, 2009).

Penelitian ini menggunakan rasio keuangan sebagai indikator kinerja keuangan. Rasio keuangan yang digunakan adalah rasio yang mengukur profitabilitas. Profitabilitas adalah kemampuan perusahaan mendapatkan laba melalui semua kemampuan dan sumber yang ada seperti kegiatan penjualan, kas, modal, jumlah karyawan, jumlah cabang dan sebagainya (Harahap, 2009). Rasio profitabilitas yang digunakan dalam penelitian ini adalah Return on Assets (ROA).

Return on Assets (ROA), rasio ini mengukur kemampuan perusahaan dalam menghasilkan laba bersih berdasarkan tingkat aktiva tertentu atau dapat dikatakan pula bahwa ROA merupakan rasio yang menggambarkan kemampuan perusahaan untuk menghasilkan keuntungan dari setiap rupiah aktiva yang digunakan. (Purwanto, 2011)

$$
R O A=\frac{E A T}{\text { Total Assets }} \times 100 \%
$$




\section{Kinerja Lingkungan}

Kinerja lingkungan adalah kinerja perusahaan dalam menciptakan lingkungan yang baik (green) (Suratno, Darsono, \& Mutmainah, 2007). Kinerja lingkungan ini dikeluarkan untuk melihat tingkat ketaatan perusahaan berdasarkan peraturan yang berlaku.

Untuk mengukur kinerja lingkungan, penelitian ini menggunakan peringkat perusahaan yang mengikuti Program Penilaian Peringkat Kinerja Perusahaan (PROPER). PROPER merupakan program pemeringkatan lingkungan dari Kementrian Lingkungan Hidup. Program ini diharapkan dapat meningkatkan kapasitas perusahaan dalam pengelolaan lingkungan hidup dan menjunjung pencapaian sasaran prioritas nasional yang termuat dalam Program Pengelolaan Sumber Daya Alam dan Lingkungan Hidup yang diukur berdasarkan indikator kinerja utama meningkatnya pengawasan ketaatan pengendalian pencemaran air limbah dan emisi; menurunnya pencemaran lingkungan pada air, udara, sampah, dan limbah B3; memastikan penghentian kerusakan lingkungan di daerah aliran sungai (DAS); tersedianya kebijakan di bidang perlindungan atmosfir dan pengendalian dampak perubahan iklim; dan meningkatnya kapasitas pengelolaan sumberdaya alam dan lingkungan hidup. (Anindito \& Ardiyanto, 2012)

\section{Corporate Social Responsibility (CSR)}

Berdasarkan Pasal 1 butir 3 Undang-Undang Republik Indonesia nomor 40 tahun 2007 tentang Perseroan Terbatas, Tanggung Jawab Sosial dan Lingkungan adalah komitmen Perseroan untuk berperan serta dalam pembangunan ekonomi berkelanjutan guna meningkatkan kualitas kehidupan dan lingkungan yang bermanfaat, baik bagi Perseroan sendiri, komunitas setempat, maupun masyarakat pada umumnya. Sementara itu, berdasarkan ISO 26000, Corporate Social Responsibility adalah tanggung jawab sebuah organisasi terhadap dampak-dampak dari keputusan-keputusan dan kegiatan-kegiatannya pada masyarakat dan lingkungan yang diwujudkan dalam bentuk perilaku transparan dan etis yang sejalan dengan pembangunan berkelanjutan dan kesejahteraan masyarakat, mempertimbangkan harapan pemangku kepentingan, sejalan dengan hukum yang ditetapkan dan norma-norma perilaku internasional, serta terintegrasi dengan organisasi secara menyeluruh. (Amelia \& Cahyati, 2015)

Corporate Social Responsibility mempunyai sebuah konsep yang terkenal yaitu konsep Triple Bottom Line. Konsep Triple Bottom Line yang dikemukakan oleh John Elkington pada tahun 1997 memberikan suatu terobosan besar bagi perkembangan CSR pada era tahun 1990-an hingga sekarang yang memasuki masa perkembangan globalisasi (Hadi, 2011). Konsep Triple Bottom Line menjelaskan bahwa CSR memiliki tiga elemen penting yaitu :

1. Perusahaan memiliki tanggung jawab terhadap Profit, yaitu untuk meningkatkan pendapatan perusahaan.

2. Perusahaan memiliki tanggung jawab terhadap People, yaitu untuk memberikan kesejahteraan kepada karyawan dan masyarakat.

3. Perusahaan memiliki tanggung jawab terhadap Planet, yaitu untuk menjaga dan meningkatkan kualitas alam serta lingkungan dimana perusahaan tersebut beroperasi.

Menurut Mathews (2015), pengungkapan pertanggungjawaban sosial disebut juga dengan social disclosure, corporate social reporting, dan social reporting yaitu merupakan proses 
mengkomunikasikan dampak sosial dan lingkungan dari kegiatan ekonomi perusahaan terhadap kelompok yang berkepentingan terhadap perusahaan secara keseluruhan (Purwanto, 2011).

Di Indonesia, kewajiban untuk pengungkapan pertanggungjawaban sosial sudah diatur dalam beberapa peraturan dan perundang-undangan. Undang-Undang Nomor 40 tahun 2007 tentang Perseroan Terbatas Pasal 66 ayat (2) butir C menyatakan bahwa Laporan Pelaksanaan Tanggung Jawab Sosial dan Lingkungan wajib disampaikan kepada RUPS setelah ditelaah oleh Dewan Komisaris dalam jangka waktu paling lambat 6 (enam) bulan setelah tahun buku Perseroan berakhir.

\section{Kerangka Berpikir dan Pengembangan Hipotesis}

Berdasarkan Undang-Undang yang mengatur, Corporate Social Responsibility atau Tanggung Jawab Sosial dan Lingkungan adalah komitmen Perseroan untuk berperan serta dalam pembangunan ekonomi berkelanjutan guna meningkatkan kualitas kehidupan dan lingkungan yang bermanfaat, baik bagi Perseroan sendiri, komunitas setempat, maupun masyarakat pada umumnya. Ada banyak faktor yang mempengaruhi pengungkapan CSR dalam suatu perusahaan. Penelitian ini berfokus pada bagaimana ukuran perusahaan, kinerja keuangan, dan kinerja lingkungan mempengaruhi pengungkapan tersebut. Dengan demikian, ukuran perusahaan, kinerja keuangan, dan kinerja lingkungan adalah variabel independen yang diteliti sedangkan pengungkapan Corporate Social Responsibility adalah variabel dependen.

\section{Hubungan antara Ukuran Perusahaan terhadap Pengungkapan Corporate Social Responsibility (CSR)}

Semakin besar ukuran perusahaan, maka semakin besar juga inisiatif untuk mengungkapkan suatu informasi. Selain memiliki inisiatif, perusahaan besar juga memiliki kemampuan dan pengetahuan yang cukup untuk mengungkapkan informasi dalam suatu laporan, dalam hal ini adalah informasi CSR dalam laporan keberlanjutan. Penelitian terdahulu (Setiawati \& Lim, 2018) (Purwanto, 2011) menunjukkan adanya hubungan positif dan signifikan antara ukuran perusahaan dan pengungkapan CSR. Dengan demikian, sejalan dengan penelitian sebelumnya, hipotesis penelitian ini adalah:

H1: Ukuran perusahaan berpengaruh positif terhadap pengungkapan CSR.

\section{Hubungan antara Kinerja Keuangan terhadap Pengungkapan Corporate Social Responsibility (CSR)}

Kinerja keuangan dapat diukur dengan berbagai metode. Namun, penelitian ini akan berfokus pada 1 rasio yaitu Return on Assets (ROA). ROA dapat menggambarkan kinerja keuangan karena ROA menggambarkan bagaimana perusahaan menghasilkan keuntungan dari setiap rupiah aktiva yang digunakan. Kinerja keuangan berpengaruh terhadap pengungkapan CSR. Hal ini dikarenakan tanggung jawab perusahaan terhadap stakeholder tidak hanya berkaitan dengan kinerja keuangan, tetapi juga tanggung jawab terhadap lingkungan dan sosial. Penelitian terdahulu (Jumingan, 2006) (Fahrizqi, 2010) menunjukkan adanya hubungan positif dan signifikan antara kinerja keuangan dan pengungkapan CSR. Dengan demikian, sejalan dengan penelitian sebelumnya, hipotesis penelitian ini adalah:

H2: Kinerja keuangan berpengaruh positif terhadap pengungkapan CSR.

\section{Hubungan antara Kinerja Lingkungan terhadap Pengungkapan Corporate Social Responsibility (CSR)}


Kinerja lingkungan yang diukur dengan PROPER memiliki pengaruh terhadap pengungkapan CSR. Hal ini dikarenakan tidak semua perusahaan manufaktur di Indonesia mengikuti PROPER dan meraih peringkat. Perusahaan yang sudah memiliki peringkat di PROPER, sekalipun bukan peringkat emas, menunjukkan dukungannya terhadap upaya pemerintah yang diwakili Kementerian Lingkungan Hidup dalam pelestarian lingkungan hidup. Apabila perusahaan sudah mengikuti PROPER, maka dapat diasumsikan perusahaan tersebut mempedulikan hal lain selain kinerja keuangan. Perusahaan yang memiliki performa lingkungan yang baik mempunyai kecenderungan untuk mengungkapkan informasi yang lebih baik secara kuantitas maupun kualitas dibanding perusahaan yang memiliki performa lingkungan buruk. Penelitian terdahulu (Suratno, Darsono, \& Mutmainah, 2007) (Amelia \& Cahyati, 2015) menunjukkan adanya hubungan positif antara kinerja lingkungan dan pengungkapan CSR. Dengan demikian, sejalan dengan penelitian sebelumnya, hipotesis penelitian ini adalah:

H3 : Kinerja lingkungan berpengaruh positif terhadap pengungkapan CSR.

\section{Hubungan antara Ukuran Perusahaan, Kinerja Keuangan, dan Kinerja Lingkungan terhadap Pengungkapan Corporate Social Responsibility (CSR)}

Penelitian ini berusaha memperlihatkan hubungan antara ketiga variabel yang mempengaruhi pengungkapan CSR di suatu perusahaan. Penelitian ini beranggapan bahwa ukuran perusahaan memiliki pengaruh positif terhadap pengungkapan CSR, kinerja keuangan berpengaruh positif terhadap pengungkapan CSR, dan kinerja lingkungan juga memiliki pengaruh positif terhadap pengungkapan CSR. Dengan demikian, penelitian ini beranggapan bahwa (Amelia \& Cahyati, 2015) (Purwanto, 2011) (Fahrizqi, 2010):

H4: Ukuran perusahaan, kinerja keuangan, dan kinerja lingkungan secara simultan berpengaruh positif terhadap pengungkapan CSR.

\section{Model Penelitian}

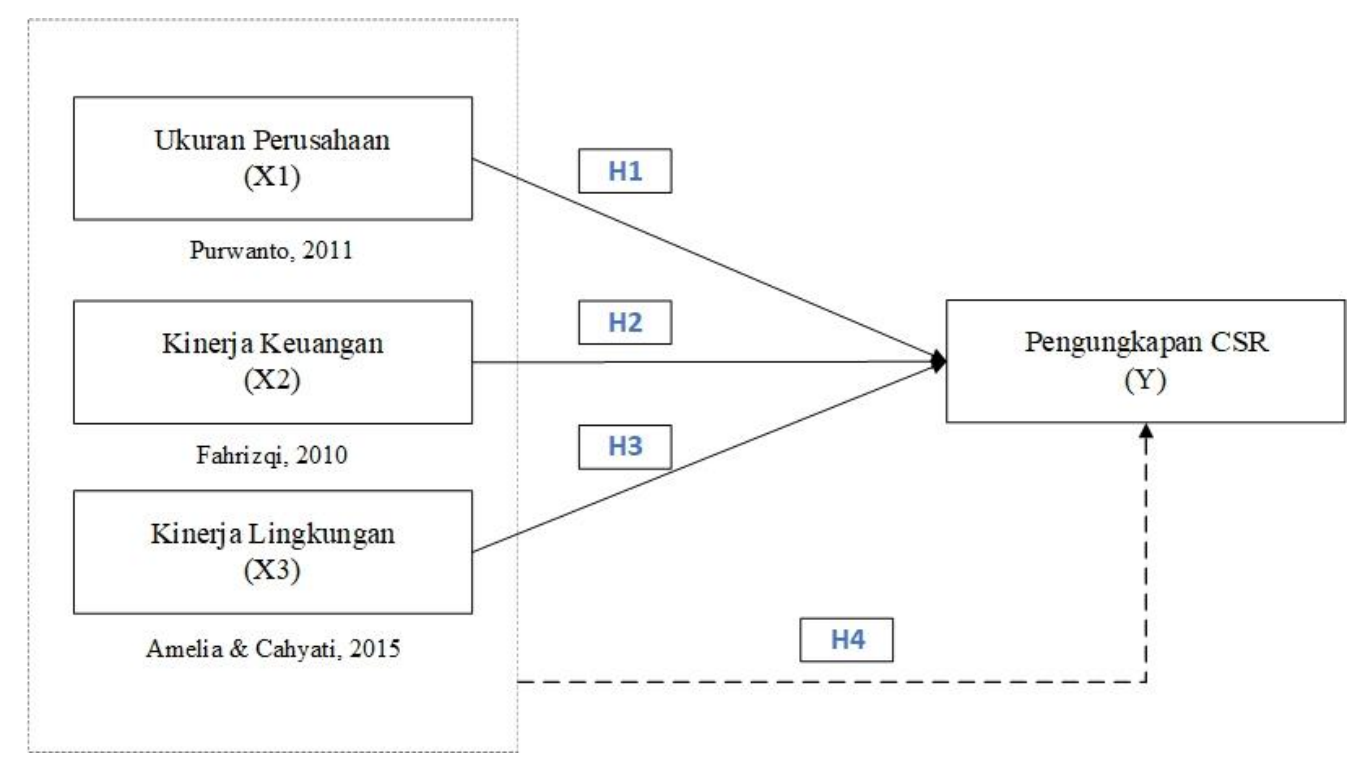

\section{METODE PENELITIAN}

\section{Jenis Penelitian}

Jenis penelitian yang digunakan dalam penelitian ini adalah kuantitatif dengan bentuk kausalitas (Kasiram, 2008). Data yang digunakan dalam penelitian ini adalah data sekunder. Data 
sekunder yang akan digunakan adalah Laporan Keuangan yang akan diperoleh dari situs resmi masing-masing perusahaan untuk mengukur ukuran perusahaan dan kinerja keuangan, Laporan Keberlanjutan yang akan diperoleh dari situs resmi masing-masing perusahaan untuk melihat pengungkapan Corporate Social Responsibility (CSR) perusahaan, dan juga data peringkat PROPER setiap tahun yang akan diperoleh dari situs resmi PROPER (proper.menlhk.go.id) untuk mengukur kinerja lingkungan perusahaan.

\section{Metode Analisis Data}

\section{Metode Regresi Linear Berganda}

Data yang diperoleh oleh peneliti akan dianalisis dengan menggunakan metode analisis regresi linear berganda. Analisis regresi linear berganda adalah alat analisis yang digunakan untuk menganalisis lebih dari satu variabel independen yang mempengaruhi variabel dependen.

Persamaan regresi dapat dirumuskan sebagai berikut:

$$
Y=a+b_{1} X_{1}+b_{2} X_{2}+b_{3} X_{3}+e
$$

$$
\begin{aligned}
& \text { Keterangan: } \\
& \alpha=\text { konstanta (intercept) } \\
& b=\text { koefisien regresi (slope) } \\
& X_{1}=\text { ukuran perusahaan } \\
& X_{2}=\text { kinerja keuangan } \\
& X_{3}=\text { kinerja lingkungan } \\
& e=\text { error }
\end{aligned}
$$

\begin{tabular}{|c|c|c|c|}
\hline Variabel & Definisi Variabel & Indikator & Skala \\
\hline $\begin{array}{l}\text { Ukuran } \\
\text { Perusahaan }\end{array}$ & $\begin{array}{l}\text { Variabel yang } \\
\text { menggambarkan besar } \\
\text { kecilnya perusahaan yang } \\
\text { ditunjukkan dengan besar } \\
\text { kecilnya aktiva, jumlah } \\
\text { penjualan, rata-rata tingkat } \\
\text { penjualan, dan rata-rata } \\
\text { total aktiva. (Setiawati \& } \\
\text { Lim, 2018) }\end{array}$ & Ln(Total Aset) & Rasio \\
\hline Kinerja Keuangan & $\begin{array}{l}\text { Gambaran kondisi } \\
\text { keuangan perusahaan pada } \\
\text { suatu periode tertentu baik } \\
\text { menyangkut aspek } \\
\text { penghimpunan dana } \\
\text { maupun penyaluran dana, } \\
\text { yang biasanya diukur } \\
\text { dengan indikator } \\
\text { kecukupan modal, }\end{array}$ & $\begin{array}{l}\text { ROA } \\
=\frac{\text { EAT }}{\text { Total Assets }} \times 100 \%\end{array}$ & Rasio \\
\hline
\end{tabular}

\section{Operasionalisasi Variabel}

Tabel Operasionalisasi Variabel 


\begin{tabular}{|c|c|c|c|}
\hline & $\begin{array}{l}\text { likuiditas, dan profitabilitas. } \\
\text { (Jumingan, 2006) }\end{array}$ & & \\
\hline $\begin{array}{l}\text { Kinerja } \\
\text { Lingkungan }\end{array}$ & $\begin{array}{l}\text { Kinerja perusahaan dalam } \\
\text { menciptakan lingkungan } \\
\text { yang baik (green). (Suratno, } \\
\text { Darsono, \& Mutmainah, } \\
\text { 2007) }\end{array}$ & $\begin{array}{l}\text { Emas = sangat baik } \\
\text { Hijau = baik } \\
\text { Biru = cukup baik } \\
\text { Merah = buruk } \\
\text { Hitam = sangat buruk }\end{array}$ & $\begin{array}{l}\text { Ordinal } \\
\text { Skor }=5 \\
\text { Skor }=4 \\
\text { Skor }=3 \\
\text { Skor }=2 \\
\text { Skor }=1\end{array}$ \\
\hline $\begin{array}{l}\text { Pengungkapan } \\
\text { CSR }\end{array}$ & $\begin{array}{l}\text { Pengungkapan } \\
\text { pertanggungjawaban sosial } \\
\text { disebut juga dengan social } \\
\text { disclosure, corporate social } \\
\text { reporting, dan social } \\
\text { reporting yaitu merupakan } \\
\text { proses mengkomunikasikan } \\
\text { dampak sosial dan } \\
\text { lingkungan dari kegiatan } \\
\text { ekonomi perusahaan } \\
\text { terhadap kelompok yang } \\
\text { berkepentingan terhadap } \\
\text { perusahaan secara } \\
\text { keseluruhan. (Pasal } 1 \text { butir } \\
3 \text { Undang-Undang Republik } \\
\text { Indonesia nomor } 40 \text { tahun } \\
\text { 2007) }\end{array}$ & $\begin{array}{l}\quad \text { CSRI }_{x}=\frac{\Sigma X_{i}}{N} \\
\text { CSRI }_{x}=\text { Corporate } \\
\text { Social Responsibility } \\
\text { Index perusahaan X. } \\
X_{i}=\text { Variabel dummy; } \\
\text { nilai } 1 \text { jika indikator } \\
\text { diungkapkan dan nilai } \\
0 \text { jika indikator tidak } \\
\text { diungkapkan. } \\
N=\text { jumlah indikator } \\
\text { GRI yang harus } \\
\text { diungkapkan. }\end{array}$ & Rasio \\
\hline
\end{tabular}

Sumber: dari berbagai sumber

\section{HASIL DAN PEMBAHASAN}

\section{Hasil Pengumpulan Data}

Penelitian ini membahas tentang pengaruh Ukuran Perusahaan, Kinerja Keuangan, dan Kinerja Lingkungan terhadap pengungkapan CSR di perusahaan manufaktur. Penelitian ini menggunakan 10 data perusahaan dalam periode waktu 3 tahun, yaitu tahun 2017, 2018, dan 2019. Data dari penelitian ini diambil dari laporan keuangan perusahaan, laporan keberlanjutan perusahaan, dan Surat Keputusan PROPER pada periode yang bersangkutan. Berikut adalah hasil pengumpulan data dari variabel yang digunakan pada penelitian ini.

\section{Ukuran Perusahaan}

Penelitian ini menggunakan perhitungan logaritma natural dari total aset sebagai indikator dari ukuran perusahaannya. Berikut adalah data ukuran perusahaan yang dikumpulkan oleh peneliti dan telah diubah menjadi bentuk logaritma natural. 
Data Ukuran Perusahaan

\begin{tabular}{|l|c|c|c|}
\cline { 2 - 4 } \multicolumn{1}{|c|}{ PERUSAHAAN } & \multicolumn{3}{|c|}{ Ukuran Perusahaan } \\
\cline { 2 - 4 } & 2017 & 2018 & 2019 \\
\hline PEHA & 27.79 & 28.26 & 28.37 \\
\hline KLBF & 30.44 & 30.53 & 30.64 \\
\hline BFRM & 29.5 & 29.63 & 29.7 \\
\hline SMGR & 31.52 & 31.57 & 32.01 \\
\hline INTP & 30.99 & 30.96 & 30.95 \\
\hline UNVR & 30.62 & 30.64 & 30.66 \\
\hline PKLTM & 31.02 & 31.08 & 31 \\
\hline MLBI & 28.55 & 28.69 & 28.69 \\
\hline SBI & 30.61 & 30.56 & 30.6 \\
\hline PTRGR & 31.35 & 31.47 & 31.48 \\
\hline
\end{tabular}

Sumber : Olahan statistik

\section{Kinerja Keuangan}

Penelitian ini menggunakan salah satu rasio profitabilitas yaitu Return on Assets (ROA). Berikut adalah data kinerja keuangan yang telah dikumpulkan oleh peneliti.

Data Kinerja Keuangan Perusahaan

\begin{tabular}{|l|r|r|r|}
\hline & \multicolumn{1}{|c|}{2017} & \multicolumn{1}{c|}{2018} & \multicolumn{1}{c|}{2019} \\
\hline PEHA & 10.7 & 7.1 & 4.9 \\
\hline KLBF & 14.47 & 13.54 & 12.37 \\
\hline BFRM & 8.62 & 8.24 & 5.78 \\
\hline SMGR & 3.3 & 6.02 & 3 \\
\hline INTP & 6.3 & 4 & 6.6 \\
\hline UNVR & 39.3 & 46.3 & 36.1 \\
\hline PKLTM & 5.57 & 5.26 & 5.69 \\
\hline MLBI & 53 & 42.39 & 41.63 \\
\hline SBI & -3.86 & 0.04 & 2.55 \\
\hline PTRGR & 3.59 & 5.25 & 2.92 \\
\hline
\end{tabular}

Sumber: Olahan statistik

\section{Kinerja Lingkungan}

Kinerja lingkungan adalah kinerja perusahaan dalam menciptakan lingkungan yang baik (green). Kinerja lingkungan akan diukur melalui prestasi perusahaan yang mengikuti PROPER yang merupakan salah satu program yang dilakukan oleh Kementerian Lingkungan Hidup untuk mendorong perusahaan dalam pengelolaan lingkungan hidup. Berikut adalah data kinerja lingkungan berdasarkan PROPER yang telah dikumpulkan dan diberi skor. 
Data Kinerja Lingkungan

\begin{tabular}{|l|c|c|c|}
\cline { 2 - 4 } & 2017 & 2018 & 2019 \\
\hline PEHA & 3 & 4 & 4 \\
\hline KLBF & 4 & 4 & 4 \\
\hline BFRM & 4 & 4 & 5 \\
\hline SMGR & 4 & 4 & 4 \\
\hline INTP & 4 & 4 & 4 \\
\hline UNVR & 3 & 3 & 3 \\
\hline PKLTM & 5 & 5 & 5 \\
\hline MLBI & 4 & 3 & 3 \\
\hline SBI & 4 & 4 & 3 \\
\hline PTRGR & 3 & 4 & 4 \\
\hline
\end{tabular}

Sumber: Olahan statistik

\section{Pengungkapan CSR}

Pengungkapan CSR merupakan proses mengkomunikasikan dampak sosial dan lingkungan dari kegiatan ekonomi perusahaan terhadap kelompok yang berkepentingan terhadap perusahaan secara keseluruhan. Penelitian ini menggunakan Corporate Social Responsibility Index berdasarkan standar GRI G4. Dalam standar GRI G4, terdapat beberapa bagian yaitu GRI 200 membahas mengenai aspek ekonomi, GRI 300 membahas aspek lingkungan, dan GRI 400 membahas mengenai aspek sosial. Total pengungkapan yang seharusnya ada berdasarkan GRI G4 adalah 89 indikator. Berikut adalah hasil yang diperoleh dan telah diolah oleh peneliti.

Data Pengungkapan CSR

\begin{tabular}{|c|c|c|c|c|c|c|}
\hline \multirow[b]{2}{*}{ PERUSAHAAN } & \multicolumn{2}{|c|}{2017} & \multicolumn{2}{|c|}{2018} & \multicolumn{2}{|c|}{2019} \\
\hline & $\begin{array}{c}\text { Jumlah } \\
\text { Pengungkapan }\end{array}$ & CSRI & $\begin{array}{c}\text { Jumlah } \\
\text { Pengungkapan }\end{array}$ & CSRI & $\begin{array}{c}\text { Jumlah } \\
\text { Pengungkapan }\end{array}$ & CSRI \\
\hline PEHA & 32 & 0.36 & 32 & 0.36 & 37 & 0.42 \\
\hline KLBF & 9 & 0.1 & 13 & 0.15 & 12 & 0.13 \\
\hline BFRM & 32 & 0.36 & 54 & 0.61 & 54 & 0.61 \\
\hline SMGR & 10 & 0.11 & 13 & 0.15 & 21 & 0.24 \\
\hline INTP & 14 & 0.16 & 13 & 0.15 & 12 & 0.13 \\
\hline UNVR & 18 & 0.2 & 27 & 0.3 & 18 & 0.2 \\
\hline PKLTM & 74 & 0.83 & 74 & 0.83 & 75 & 0.84 \\
\hline MLBI & 9 & 0.1 & 8 & 0.09 & 33 & 0.37 \\
\hline SBI & 33 & 0.37 & 29 & 0.33 & 32 & 0.36 \\
\hline PTRGR & 57 & 0.64 & 57 & 0.64 & 55 & 0.62 \\
\hline
\end{tabular}

Sumber: Olahan statistik

\section{Analisis dan Pengolahan Data}

\section{Uji Statistik Deskriptif}

Data yang telah dikumpulkan diolah menggunakan software IBM SPSS 26. Data yang diolah bertujuan untuk mengumpulkan informasi terkait variabel yang diteliti. Data yang ditunjukkan 
adalah $N$ yang berarti jumlah data yang diolah, nilai minimum (Minimum), nilai maksimum (Maximum), rata-rata (Mean), dan standar deviasi (Std. Deviation).

\section{Hasil Pengolahan Statistik Deskriptif}

\section{Descriptive Statistics}

\begin{tabular}{l|r|r|r|r|r} 
& N & Minimum & Maximum & Mean & Std. Deviation \\
\hline Ln(Total Assets) & 30 & 27.79 & 32.01 & 30.3298 & 1.13648 \\
\hline Kinerja Keuangan & 30 & -3.86 & 53.00 & 13.3927 & 15.74503 \\
\hline Kinerja Lingkungan & 30 & 3.00 & 5.00 & 3.8667 & .62881 \\
\hline CSR & 30 & .09 & .84 & .3587 & .23811 \\
\hline Valid N (listwise) & 30 & & & & \\
\hline
\end{tabular}

Sumber: Data Olahan IBM SPSS Statistics 26

\section{Uji Asumsi Klasik}

Uji asumsi klasik yang digunakan pada penelitian ini ada 4 pengujian, yaitu uji normalitas, uji multikolinearitas, uji heterokedastisitas, dan uji autokorelasi. Semua pengujian dilakukan menggunakan software IBM SPSS 26.

\section{Uji Normalitas}

Hasil pengujian normalitas menunjukkan bahwa nilai Asymp. Sig. (2-tailed) sebesar 0.194. Nilai ini lebih besar daripada 0.05 , maka dapat disimpulkan bahwa data yang digunakan dalam penelitian ini telah terdistribusi normal.

\section{Hasil Uji Normalitas}

One-Sample Kolmogorov-Smirnov Test

\begin{tabular}{|c|c|c|}
\hline & & $\begin{array}{l}\text { Unstandardiz } \\
\text { ed Residual }\end{array}$ \\
\hline $\mathrm{N}$ & & 30 \\
\hline \multirow[t]{2}{*}{ Normal Parameters ${ }^{a, b}$} & Mean & .0000000 \\
\hline & Std. Deviation & .21506439 \\
\hline \multirow[t]{3}{*}{ Most Extreme Differences } & Absolute & .132 \\
\hline & Positive & .132 \\
\hline & Negative & -.097 \\
\hline Test Statistic & & .132 \\
\hline Asymp. Sig. (2-tailed) & & $.194^{\mathrm{c}}$ \\
\hline
\end{tabular}

Sumber : Data Olahan IBM SPSS Statistics 26

\section{Uji Multikolinearitas}

Hasil uji multikolinearitas menunjukkan bahwa nilai Colinearity Tolerance untuk setiap variabel lebih besar daripada 0.01 dan juga nilai Statistics VIF lebih kecil dari 10. Dapat disimpulkan bahwa tidak ada gejala multikolinearitas yang terjadi pada model regresi penelitian ini. 


\section{Hasil Uji Multikolinearitas}

\begin{tabular}{|c|c|c|c|c|c|c|c|c|}
\hline \multicolumn{9}{|c|}{ Coefficients $^{a}$} \\
\hline \multirow[b]{2}{*}{ Model } & & \multicolumn{2}{|c|}{ Unstandardized Coefficients } & \multirow{2}{*}{$\begin{array}{l}\text { Standardized } \\
\text { Coefficients } \\
\text { Beta }\end{array}$} & \multirow[b]{2}{*}{$t$} & \multirow[b]{2}{*}{ Sig. } & \multicolumn{2}{|c|}{ Collinearity Statistics } \\
\hline & & B & Std. Error & & & & Tolerance & VIF \\
\hline \multirow[t]{4}{*}{1} & (Constant) & .131 & 1.262 & & .104 & .918 & & \\
\hline & Ln(Total Assets) & -.010 & .040 & -.047 & -.252 & .803 & .846 & 1.182 \\
\hline & Kinerja Keuangan & -.003 & .003 & -.182 & -.872 & .391 & .669 & 1.496 \\
\hline & Kinerja Lingkungan & .151 & .078 & 386 & 1.940 & .063 & .740 & 1.351 \\
\hline
\end{tabular}

a. Dependent Variable: CSR

Sumber : Data Olahan IBM SPSS Statistics 26

\section{Uji Heteroskedastisitas}

Hasil uji heteroskedastisitas menunjukkan bahwa nilai signifikansi yang disimbolkan dengan Sig. untuk semua variabel menunjukkan nilai yang lebih dari 0.05. Dengan demikian, dapat disimpulkan bahwa tidak terjadi gejala heteroskedastisitas pada model regresi penelitian ini.

\section{Hasil Uji Heteroskedastisitas}

\begin{tabular}{|c|c|c|c|c|c|c|}
\hline \multicolumn{7}{|c|}{ Coefficients $^{a}$} \\
\hline \multirow[b]{2}{*}{ Model } & & \multicolumn{2}{|c|}{ Unstandardized Coefficients } & \multirow{2}{*}{$\begin{array}{c}\text { Standardized } \\
\text { Coefficients } \\
\text { Beta }\end{array}$} & \multirow[b]{2}{*}{$\mathrm{t}$} & \multirow[b]{2}{*}{ Sig. } \\
\hline & & B & Std. Error & & & \\
\hline \multirow[t]{4}{*}{1} & (Constant) & -4.423 & 1.568 & & -2.820 & .009 \\
\hline & Kinerja Keuangan & .009 & .004 & .433 & 2.149 & .041 \\
\hline & Kinerja Lingkungan & .120 & .097 & .237 & 1.238 & .227 \\
\hline & Ln(Total Assets) & .145 & .050 & .518 & 2.888 & .008 \\
\hline
\end{tabular}

a. Dependent Variable: abs_res2

\section{Sumber: Data Olahan IBM SPSS Statistics 26}

\section{Uji Autokorelasi}

Hasil uji autokorelasi menunjukkan bahwa nilai Durbin Watson yang diperoleh adalah 1.702. Berdasarkan tabel Durbin Watson untuk penelitian dengan $a=5 \%$, nilai dL dan dU untuk variabel dengan 3 variabel independen dan jumlah data 30 adalah sebesar 1.2138 (dL) dan 1.6498 (dU). Dengan demikian dapat disimpulkan bahwa tidak terjadi gejala autokorelasi pada model regresi penelitian ini karena nilainya berada di antara dU (1.6498) dan 4 - du sebesar 2.3502 $(1.6498<1.702<2.3502)$.

\section{Hasil Uji Autokorelasi}

\begin{tabular}{ll|r|r|r|r}
\multicolumn{7}{c}{} & \multicolumn{2}{c}{ Model Summary } \\
Model & R & R Square & $\begin{array}{c}\text { Adjusted R } \\
\text { Square }\end{array}$ & $\begin{array}{c}\text { Std. Error of } \\
\text { the Estimate }\end{array}$ & $\begin{array}{c}\text { Durbin- } \\
\text { Watson }\end{array}$ \\
\hline 1 & $.570^{\text {a }}$ & .325 & .244 & .18919 & 1.702 \\
\hline
\end{tabular}

a. Predictors: (Constant), $\operatorname{lag} \times 33, \operatorname{lag} x 1, \operatorname{lag} \times 2$

b. Dependent Variable: lag_y 


\section{Uji Hipotesis}

\section{Uji Parsial (Uji Statistik t)}

Uji statistik t digunakan untuk mengetahui pengaruh masing-masing variabel independen secara individual terhadap variabel dependen.

\section{Hasil Uji Statistik t}

\begin{tabular}{|c|c|c|c|c|c|c|}
\hline \multicolumn{7}{|c|}{ Coefficients $^{a}$} \\
\hline \multirow[b]{2}{*}{ Model } & & \multicolumn{2}{|c|}{ Unstandardized Coefficients } & \multirow{2}{*}{$\begin{array}{c}\text { Standardized } \\
\text { Coefficients } \\
\text { Beta }\end{array}$} & \multirow[b]{2}{*}{$t$} & \multirow[b]{2}{*}{ Sig. } \\
\hline & & $\mathrm{B}$ & Std. Error & & & \\
\hline \multirow[t]{4}{*}{1} & (Constant) & .152 & 1.218 & & .125 & .901 \\
\hline & Ln(Total Assets) & -.011 & .039 & -.050 & -.270 & .789 \\
\hline & Kinerja Keuangan & -.003 & .003 & -.186 & -.890 & .382 \\
\hline & Kinerja Lingkungan & .146 & .075 & .384 & 1.934 & .064 \\
\hline
\end{tabular}

a. Dependent Variable: CSR

Sumber: Data Olahan IBM SPSS Statistics 26

Berdasarkan tabel diatas, dapat dilihat bahwa:

- Nilai Sig. Ln(Total Assets) yang merupakan indikator dari ukuran perusahaan adalah sebesar 0.901. Nilai ini lebih besar daripada 0.05 sehingga dapat disimpulkan bahwa H1 ditolak.

- Nilai Sig Kinerja Keuangan yang diukur dengan rasio ROA adalah sebesar 0.789. Nilai ini lebih besar daripada 0.05 sehingga dapat disimpulkan bahwa $\mathrm{H} 2$ ditolak.

- Nilai Sig Kinerja Lingkungan yang diukur dengan ranking PROPER adalah sebesar 0.064. Nilai ini lebih besar daripada 0.05 sehingga dapat disimpulkan bahwa H3 ditolak.

\section{Uji Simultan (Uji Statistik F)}

Uji statistik $\mathrm{f}$ digunakan untuk mengetahui pengaruh variabel independen secara bersamasama terhadap variabel dependen. Jika:

\section{Hasil Uji Statistik F}

\begin{tabular}{|c|c|c|c|c|c|c|}
\hline \multicolumn{7}{|c|}{ ANOVA $^{a}$} \\
\hline \multicolumn{2}{|c|}{ Model } & $\begin{array}{l}\text { Sum of } \\
\text { Squares }\end{array}$ & df & Mean Square & $\mathrm{F}$ & Sig. \\
\hline \multirow[t]{3}{*}{1} & Regression & .396 & 3 & .132 & 2.746 & $.063^{b}$ \\
\hline & Residual & 1.249 & 26 & .048 & & \\
\hline & Total & 1.644 & 29 & & & \\
\hline
\end{tabular}

a. Dependent Variable: CSR

b. Predictors: (Constant), Kinerja Lingkungan, Ln(Total Assets), Kinerja Keuangan 
Berdasarkan data di atas, dapat dilihat bahwa nilai Signifikansi F sebesar 0.63. Nilai ini lebih besar daripada 0.05. Dengan demikian, dapat disimpulkan bahwa variabel penelitian yaitu ukuran perusahaan, kinerja keuangan, dan kinerja lingkungan tidak memiliki pengaruh yang signifikan terhadap pengungkapan CSR.

\section{Pembahasan Hasil Penelitian}

\section{Pengaruh Ukuran Perusahaan terhadap Pengungkapan CSR}

Berdasarkan penelitian yang telah dilakukan, dapat diketahui bahwa ukuran perusahaan yang diukur dengan nilai logaritma natural total aset perusahaan, secara parsial tidak berpengaruh terhadap pengungkapan CSR. Hal ini ditunjukkan dengan nilai signifikansi t yang lebih besar daripada 0.05, yaitu sebesar 0.789. Hasil dari penelitian ini tidak sejalan dengan penelitian yang dilakukan oleh (Purwanto, 2011). Namun, hasil dari penelitian ini sejalan dengan penelitian lain yang serupa, yang dilakukan oleh (Mandaika \& Salim, 2015). Penelitian yang dilakukan oleh Mandaika dan Salim pada tahun 2015 beranggapan bahwa tidak semua perusahaan besar dengan jumlah aset yang banyak melakukan pengungkapan CSR. Ada kemungkinan bahwa perusahaan lebih berfokus pada pencapaian kinerja keuangan dibanding kinerja sosial dan lingkungan.

Tidak semua perusahaan besar melakukan pengungkapan CSR yang komprehensif pada laporan keberlanjutan mereka. Bahkan, tidak sedikit perusahaan besar yang sama sekali tidak membuat laporan keberlanjutan. Walaupun demikian, mayoritas perusahaan sudah memahami tanggung jawab sosial atau CSR ini, dibuktikan dengan banyaknya perusahaan yang sudah melakukan pengungkapan CSR pada laman resmi perusahaan mereka. Namun pengungkapan tersebut hanya menggambarkan garis besar kegiatan yang mereka lakukan dan banyak pula yang hanya menjelaskan mengenai apa yang dilakukan perusahaan dalam bidang sosial. Padahal seperti yang kita ketahui, pengungkapan CSR berdasarkan standar GRI G4 tidak terbatas pada bidang sosial, melainkan ada bidang ekonomi dan lingkungan juga yang menjadi inti dari CSR ini.

\section{Pengaruh Kinerja Keuangan terhadap Pengungkapan CSR}

Berdasarkan penelitian yang terlah dilakukan, dapat diketahui bahwa kinerja keuangan yang digambarkan dengan rasio Return on Assets (ROA) tidak berpengaruh secara parsial terhadap pengungkapan CSR di suatu perusahaan. Hal ini ditunjukkan dengan nilai signifikansi t sebesar 0.382 yang lebih besar daripada 0.05. Hasil dari penelitian ini tidak sejalan dengan penelitian yang dilakukan oleh (Fahrizqi, 2010). Namun, hasil dari penelitian ini sejalan dengan penelitian yang dilakukan oleh (Mandaika \& Salim, 2015). Penelitian yang dilakukan oleh Mandaika dan Salim pada tahun 2015 beranggapan bahwa masih banyaknya perusahaan yang tidak menganggap CSR sebagai suatu investasi jangka panjang, namun hanya sebagai pengurang laba. Banyak juga yang menganggap bahwa pengungkapan CSR pada saat profitabilitas tinggi hanya akan mengganggu kesuksesan.

Penelitian ini pada awalnya mempercayai bahwa kinerja keuangan berpengaruh terhadap pengungkapan CSR. Hal ini dikarenakan tanggung jawab perusahaan terhadap stakeholder tidak hanya berkaitan dengan kinerja keuangan, tetapi juga tanggung jawab terhadap lingkungan dan sosial. Selain itu, dengan kinerja keuangan yang baik, maka perusahaan dianggap mampu mengalokasikan dana untuk kegiatan CSR di bidang lingkungan dan sosial. Namun pada kenyataannya, banyak perusahaan yang masih berfokus pada capaian kinerja keuangan saja. Seperti yang diungkapkan oleh Mandaika dan Salim pada penelitiannya, banyak perusahaan yang menganggap CSR ini hanyalah pengurang laba dengan tidak memberikan manfaat yang jelas. 


\section{Pengaruh Kinerja Lingkungan terhadap Pengungkapan CSR}

Berdasarkan penelitian yang telah dilakukan, dapat diketahui bahwa kinerja lingkungan yang digambarkan dengan skor peringkat PROPER tidak berpengaruh secara parsial terhadap pengungkapan CSR di suatu perusahaan. Hal ini ditunjukkan dengan nilai signifikansi t sebesar 0.064 yang lebih besar daripada 0.05 . Hasil dari penelitian ini tidak sejalan dengan penelitian (Amelia \& Cahyati, 2015).

Anggapan bahwa perusahaan yang sudah mengikuti PROPER ini pasti melakukan pengungkapan CSR tidaklah benar. Pada kenyataannya, dalam proses pencarian data pun terdapat kesulitan untuk mencari perusahaan yang mengikuti PROPER dan menerbitkan Laporan Keberlanjutan. Bahkan, perusahaan yang menerima peringkat Emas pun tidak semuanya menerbitkan Laporan Keberlanjutan sehingga penelitian harus mengambil sampel perusahaan yang memperoleh peringkat lain seperti peringkat Hijau dan Biru, untuk peringkat Merah dan Hitam tidak bisa diukur karena tidak tersedianya Laporan Keberlanjutan perusahaan-perusahaan yang memperoleh peringkat tersebut. Dengan tidak menyeluruhnya sampel yang digunakan, sulit untuk melihat hubungan yang signifikan antara kinerja lingkungan dan pengungkapan CSR. Selain itu, perusahaan yang sudah memperoleh peringkat yang cukup baik seperti Hijau dan Biru pun, tidak semuanya melakukan pengungkapan CSR sesuai dengan standar. Sama seperti perusahaan yang memperoleh peringkat Emas, masih banyak perusahaan yang memperoleh peringkat Hijau maupun Biru yang belum membuat Laporan Keberlanjutan. Dengan demikian, dapat disimpulkan bahwa apabila perusahaan sudah memiliki kinerja lingkungan yang cukup baik, tidak serta-merta mempunyai kesadaran untuk membuat Laporan Keberlanjutan. Mungkin perusahaan sudah tidak hanya berfokus pada kinerja keuangan saja, namun juga sudah mulai focus terhadap kinerja lingkungan, namun, seperti yang sama-sama kita ketahui bahwa CSR tidak hanya lingkungan saja yang menjadi poin utama, melainkan ada bidang ekonomi dan sosial yang menjadi pilar dari keberlanjutan sehingga tidak bisa hanya mengandalkan kinerja lingkungan saja.

\section{Pengaruh Ukuran Perusahaan, Kinerja Keuangan, dan Kinerja Lingkungan terhadap Pengungkapan CSR}

Berdasarkan penelitian yang telah dilakukan, dapat diketahui bahwa ukuran perusahaan, kinerja keuangan, dan kinerja lingkungan tidak berpengaruh secara simultan terhadap pengungkapan CSR di suatu perusahaan. Hal ini ditunjukkan dengan nilai signifikansi F yang lebih besar daripada 0.05 , yaitu sebesar 0.063 .

Ukuran perusahaan, kinerja keuangan, dan kinerja lingkungan tidak berpengaruh secara simultan terhadap pengungkapan CSR. Anggapan awal dalam penelitian ini adalah 3 faktor yang diteliti ini dianggap sebagai faktor yang paling penting dan mempengaruhi pengungkapan CSR di suatu perusahaan. Namun, berdasarkan hasil penelitian ternyata ketiga faktor ini belum bisa memperlihatkan hubungan yang kuat. Hal ini disebabkan karena adanya faktor-faktor lain yang dapat mempengaruhi pengungkapan CSR, namun tidak diteliti dalam penelitian ini. Contohnya adalah tipe perusahaan, leverage, ukuran dewan komisaris, dan masih banyak lagi. 


\section{KESIMPULAN DAN SARAN}

\section{Kesimpulan}

Berdasarkan hasil penelitian yang telah dilakukan mengenai Pengaruh Ukuran Perusahaan, Kinerja Keuangan, dan Kinerja Lingkungan terhadap Pengungkapan Corporate Social Responsibility (CSR) pada Perusahaan Manufaktur di Indonesia, maka dapat ditarik kesimpulan :

1. Ukuran perusahaan yang diukur dengan logaritma natural total aset tidak berpengaruh secara parsial terhadap pengungkapan CSR.

2. Kinerja keuangan yang diukur dengan rasio Return on Asset (ROA) tidak berpengaruh secara parsial terhadap pengungkapan CSR.

3. Kinerja lingkungan yang diukur dengan peringkat PROPER tidak berpengaruh secara parsial terhadap pengungkapan CSR.

4. Ukuran perusahaan, kinerja keuangan, dan kinerja lingkungan tidak berpengaruh secara simultan terhadap pengungkapan CSR.

\section{Saran}

\section{Bagi pemerintah}

Melihat fenomena bahwa masih banyak perusahaan yang belum melakukan pengungkapan CSR, pemerintah dapat memberikan lebih banyak sosialisasi mengenai pentingnya CSR dalam suatu perusahaan. Terlebih lagi mengenai manfaat yang diperoleh apabila melakukan pengungkapan CSR. Selain itu, pemerintah juga dapat mensosialisasikan lagi mengenai standar yang dapat digunakan ketika perusahaan melakukan pengungkapan. Dengan demikian, diharapkan perusahaan menjadi terdorong untuk melakukan pengungkapan CSR.

\section{Bagi peneliti selanjutnya}

Peneliti selanjutnya disarankan untuk menambah jumlah sampel yang diteliti dan juga rentang waktu yang diteliti. Selain itu, peneliti selanjutnya juga disarankan untuk menambah variabel independen lainnya berupa faktor-faktor lain yang dapat mempengaruhi pengungkapan CSR sehingga penelitian dapat dilakukan dengan lebih menyeluruh. Peneliti selanjutnya juga dapat memilih sektor usaha lain selain industri manufaktur.

\section{DAFTAR PUSTAKA}

Amelia, \& Cahyati, A. D. (2015). Pengaruh Kinerja Keuangan, Kinerja Lingkungan, Size, dan Ukuran Dewan Komisaris terhadap CSR Disclosure. JRAK. Vol.6 No.2 Agusuts 2015, 64-79.

Anindito, T., \& Ardiyanto, M. D. (2012). Pengaruh Kinerja Lingkungan terhadap Corporate Social Responsibility (CSR) Disclosure dan Kinerja Finansial Perusahaan Kimia dan Pertambangan Yang Terdaftar Di Bursa Efek Indonesia. Diponegoro Journal of Accounting, $1-12$.

Fahrizqi, A. (2010). Faktor-Faktor yang Mempengaruhi Pengungkapan Corporate Social Responsibility (CSR) dalam Laporan Tahunan Perusahaan. SKRIPSI.

Hadi. (2011). Corporate Social Responsibility. Yogyakarta: Graha Ilmu.

Harahap, S. S. (2009). Teori Kritis Laporan Keuangan. Jakarta: Bumi Aksara. 
Jumingan. (2006). Analisis Laporan Keuangan, Cetakan Pertama. Jakarta: PT Bumi Aksara.

Karawang News Industry City. (2019, July 12). Perkembangan Industri Manufaktur Indonesia. Retrieved April 26, 2021, from Karawang News Industry City: https://www.knic.co.id/id/perkembangan-industri-manufaktur-indonesia

Kasiram. (2008). Metodologi Penelitian Kualitatif dan Kuantitatif. Malang: UIN Maliki Press.

Kencana, M. R. (2019, April 25). BEI Dorong Perusahaan Tercatat Terapkan Pembangunan Berkelanjutan. Retrieved April 8, 2021, from Liputan6.com: https://www.liputan6.com/bisnis/read/3950084/bei-dorong-perusahaan-tercatatterapkan-pembangunan-berkelanjutan

Mandaika, Y., \& Salim, H. (2015). Pengaruh Ukuran Perusahaan, Kinerja Keuangan, Tipe Industri, dan Financial Leverage terhadap Pengungkapan Corporate Social Responsibility: Studi Empiris pada Perusahaan Manufaktur yang Terdaftar di Bursa Efek Indonesia Tahun 2011-2013. Jurnal Akuntansi, 181-201.

Purwanto, A. (2011). Pengaruh Tipe Industri, Ukuran Perusahaan, Profitabilitas terhadap Corporate Social Responsibility. Jurnal Akuntansi dan Auditing, vol. 8, no. 1, 12-29.

Setiawati, L. W., \& Lim, M. (2018). Analisis Pengaruh Profitabilitas, Ukuran Perusahaan, Leverage, dan Pengungkapan Sosial terhadap Nilai Perusahaan pada Perusahaan Manufaktur yang Terdaftar di Bursa Efek Indonesia Periode 2011-2015. Jurnal Akuntansi, 29-57.

Suratno, I. B., Darsono, D., \& Mutmainah, S. (2007). Pengaruh Environmental Performance Terhadap Environmental Disclosure dan Economic Performance (Studi Empiris pada Perusahaan Manufaktur yang terdaftar di BEJ Periode 2001-2004). The Indonesian Journal of Accounting Research.

Sutrisno. (2009). Manajemen Keuangan Teori, Konsep, dan Aplikasi. Yogyakarta: Ekonisia. 